\title{
FMR1 and the fragile $X$ syndrome: Human genome epidemiology review
}

\author{
Dana C. Crawford, $P h D^{1,2}$, Juan M. Acuña, $M D^{3,4}$, and Stephanie L. Sherman, $P h D^{5}$
}

\begin{abstract}
The fragile $\mathrm{X}$ syndrome, an X-linked dominant disorder with reduced penetrance, is one of the most common forms of inherited mental retardation. The cognitive, behavioral, and physical phenotype varies by sex, with males being more severely affected because of the X-linked inheritance of the mutation. The disorder-causing mutation is the amplification of a CGG repeat in the 5' untranslated region of FMR1 located at Xq27.3. The fragile X CGG repeat has four forms: common (6-40 repeats), intermediate (41-60 repeats), premutation (61-200 repeats), and full mutation (>200-230 repeats). Population-based studies suggest that the prevalence of the full mutation, the disorder-causing form of the repeat, ranges from 1/3,717 to 1/8,918 Caucasian males in the general population. The full mutation is also found in other racial/ethnic populations; however, few population-based studies exist for these populations. No population-based studies exist for the full mutation in a general female population. In contrast, several large, population-based studies exist for the premutation or carrier form of the disorder, with prevalence estimates ranging from 1/246 to $1 / 468$ Caucasian females in the general population. For Caucasian males, the prevalence of the premutation is $\sim 1 / 1,000$. Like the full mutation, little information exists for the premutation in other populations. Although no effective cure or treatment exists for the fragile $\mathrm{X}$ syndrome, all persons affected with the syndrome are eligible for early intervention services. The relatively high prevalence of the premutation and full mutation genotypes coupled with technological advances in genetic testing make the fragile $X$ syndrome amenable to screening. The timing as well as benefits and harms associated with the different screening strategies are the subject of current research and discussion. Genet Med 2001:3(5):359-371.
\end{abstract}

Key Words: fragile $X$ syndrome, FMR1, FRAXA, mental retardation, epidemiology, review

\section{FMR1 AND FMRP}

FMR1, located at Xq27.3, consists of 17 exons and is approximately $38 \mathrm{~kb}$ in size. ${ }^{1,2}$ The mRNA is approximately $4.4 \mathrm{~kb}$ and contains $1.9 \mathrm{~kb}$ of coding sequence. Within the 5 ' untranslated region (UTR) of FMR1 is a polymorphic CGG repeat coincident with a rare fragile site on the $\mathrm{X}$ chromosome known as FRAXA. FRAXA was a cytogenetic marker instrumental in the identification of patients and, ultimately, the gene itself (see Disease section, below).

FMR1 is highly conserved at the sequence and amino acid level as evidenced by its presence in the human, mouse, Caenorhabditis elegans, Xenopus laevis, Drosophila melanogaster,

\footnotetext{
From the ${ }^{1}$ Centers for Disease Control and Prevention, Epidemic Intelligence Service, Division of Applied Public Health Training, Epidemiology Program Office; ${ }^{2}$ Centers for Disease Control and Prevention, National Center on Birth Defects and Developmental Disabilities; ${ }^{3} \mathrm{Cen}$ ters for Disease Control and Prevention, National Center for Chronic Disease Prevention and Health Promotion, Division of Reproductive Health, CDC Assignee to the Louisiana Office of Public Health; ${ }^{4}$ National University of Colombia; and ${ }^{5}$ Department of Genetics, Emory University School of Medicine, Atlanta, Georgia.

Dana C. Crawford, PhD, Centers for Disease Control and Prevention, National Center on Birth Defects and Developmental Disabilities, 4770 Buford Highway NE, MS F-45, Atlanta, GA 30341 .

Received: May 2, 2001.
}

Accepted: June 20, 2001 and chicken. ${ }^{1,3-6} F M R 1$ is widely expressed in both human and mouse embryos, with the highest expression located in the brain, testes, ovaries, esophageal epithelium, thymus, eye, and spleen. ${ }^{7}$ Extensive alternative splicing of the $3^{\prime}$ end of the gene produces different mRNAs and isoforms of the protein, each predicted to have distinct biochemical properties ${ }^{1}$ (reviewed in Warren and Sherman). ${ }^{8}$ Only a few isoforms are commonly detected in lymphoblasts; however, the existence of other predicted isoforms in different cell types has not been thoroughly investigated. ${ }^{8}$

The fragile $\mathrm{X}$ mental retardation protein (FMRP) is the protein product of FMR1. FMRP contains two ribonucleoprotein $\mathrm{K}$ homology domains ( $\mathrm{KH}$ domains) and clusters of arginine and glycine residues (RGG boxes), two features commonly associated with RNA-binding proteins. ${ }^{1,9} \mathrm{FMRP}$ binds in vitro to itself as well as to two fragile X-related autosomal homologs, FXR1P and FXR2P. ${ }^{10}$ However, some experiments suggest that these FXR interactions may not exist in vivo. ${ }^{11-13}$ Also, recent experiments in rabbit reticulocyte lysate and X. laevis oocytes demonstrate that FMRP strongly inhibits translation of various mRNAs at nanomolar concentrations, an effect not seen with its homologs FXR1P and FXR2P. ${ }^{14}$

In addition to its RNA-binding properties, FMRP contains both a nuclear localization signal (NLS) and a nuclear export signal (NES). ${ }^{15}$ The current model suggests that oligomerized 
FMRP, in conjunction with other proteins, shuttles specific mRNAs from the nucleus to the cytoplasm for translation. Consistent with this model is the RNA-dependent association of FMRP with actively translating polyribosomes. ${ }^{16,17}$ Also, other proteins such as nucleolin and nuclear FMRP interacting protein (NUFIP) have been shown to interact with FMRP, possibly modulating mRNA binding to FMRP. ${ }^{18,19}$ Furthermore, recent experiments based on the fragile $\mathrm{X}$ patient with a Ile to Asn substitution at amino acid position 304 (I304N) suggest that FMRP must oligomerize to properly modulate the transcription of these other mRNAs. ${ }^{14}$ Finally, although FMRP has been shown to be primarily a cytoplasmic protein, ${ }^{20,21}$ recent immunogold experiments have localized FMRP in the neuronal nucleoplasm and within the nuclear pore, ${ }^{22}$ suggesting nuclear export capabilities. Inconsistent with this model, however, is the observation that the D. melanogaster homolog, dFMR1, remains in the nucleus even though the conserved NES is present. ${ }^{6}$ Despite this inconsistency of biological conservation and significance, identification of the specific, shuttled mRNAs and their respective genes as well as modulating proteins will greatly increase the understanding of FMRP's role in the fragile $\mathrm{X}$ syndrome phenotype.

\section{FMR1 CGG REPEAT VARIANTS}

The FMR1 polymorphic CGG repeat located in the 5' UTR of the gene can be categorized in at least four forms based on the size of the repeat: full mutation ( $>200-230$ repeats), premutation (61-200 repeats), intermediate (41-60 repeats), and common (6-40 repeats). Among the general population, the common repeats are usually transmitted from parent to offspring in a stable manner. Intermediate alleles are larger repeats that may or may not be transmitted stably from parent to offspring. Thus, these alleles overlap the boundary between common and premutation alleles. ${ }^{23}$ While intermediate alleles may be unstable, very few expand to the disorder-causing mutation in the next generation. Recent evidence, in fact, suggests that intermediate alleles identified among families with the fragile X syndrome are more susceptible to disorder-causing expansions in the next generation compared with intermediate alleles identified in the general population. ${ }^{23-26}$ To date, 59 repeats is the smallest size known to expand to the disordercausing mutation in the next generation within a family with the fragile $\mathrm{X}$ syndrome. ${ }^{23,24}$ More prospective studies are needed to better quantify the risks of disorder-causing expansions for the purpose of genetic counseling the women identified with intermediate alleles.

Unlike common and intermediate alleles, premutation alleles are unstable when transmitted from parent to offspring and usually expand in the next generation. The size of the repeat expansion is positively correlated with maternal CGG repeat size, with $>90$ repeats almost always expanding to the full mutation in the next generation. ${ }^{25}$ The transition from premutation to full mutation is thought to occur prezygotically. ${ }^{27,28}$ In contrast to the female germline, paternal transmission of the full mutation to the offspring is rare. Recent studies suggest that selection against full mutation in sperm is responsible for the differences observed between female and male germline transmissions. ${ }^{27,29}$

The full mutation allele is the form associated with the fragile X syndrome phenotype. All full mutations identified to date are derived from premutation or full mutation alleles from the previous generation. The full mutation allele leads to hypermethylation $^{30}$ and deacetylation ${ }^{31}$ of FMR1, which effectively shuts down transcription of the gene. ${ }^{32}$

Since the molecular characterization of the CGG repeat in $1991,{ }^{33}$ most forms of the repeat have been characterized in all populations studied. This review describes the genotype frequencies of the full mutation and premutation, as both of these are directly related to the expression of the fragile $\mathrm{X}$ syndrome phenotype.

\section{FULL MUTATION}

Before the cloning of FMR1, the inducible FRAXA fragile site was developed as a cytogenetic marker and proved valuable in diagnosing this nonspecific form of X-linked mental retardation. ${ }^{34}$ Several studies published in the 1980s using the fragile site as a diagnostic tool estimated that the prevalence of the syndrome was as high as 1 in 1,500 males and 1 in 2,500 females in the general population..$^{35,36}$ The cytogenetic test employed by these studies has since been shown to be inaccurate, generating both false-negative and false-positive results. ${ }^{37}$

The cloning of the CGG repeat responsible for the fragile X syndrome provided the opportunity for a more accurate diagnosis using molecular techniques. For this review, published studies (abstracts excluded) that employed DNA-based screening for the fragile X syndrome were considered and described in Table 1. Most studies to date have screened target populations (e.g., special education or mentally retarded populations), yet only a few extrapolated these results to the general population (12/39 studies; Table 1). For these few studies, the general assumption is that all males with the fragile $\mathrm{X}$ syndrome will be mentally impaired to some significant degree and will be found only among the targeted population.

\section{Full mutation and males: Caucasian populations of northern European descent}

For the Caucasian population, the point estimates for eight studies suggest that the prevalence of the fragile $\mathrm{X}$ syndrome ranges from 1 in $3,717^{38}$ to 1 in $8,918^{39}$ males in the general population. The confidence limits, available for only four of these studies, vary widely, with a lower boundary of 1 in $1,333^{40}$ to an upper boundary of 1 in $8,922 .{ }^{41}$ Three studies summarized in Table 1 did not report point estimates: two ${ }^{42,43}$ provided a range and one ${ }^{44}$ provided a lower boundary, all of which fall within the point estimates and confidence intervals reported in the other studies (Table 1).

The problem encountered by all these studies is the extrapolation of the prevalence in the phenotypically-defined target population to that in the general population. Comparison of studies is also complicated because of the differences in the 
definitions of the target populations. For example, a study that examined clinically referred persons with mental retardation found a higher prevalence for fragile $\mathrm{X}$ in the target population ${ }^{45}$ compared with a study that examined persons with language delay. ${ }^{46}$ Given the clinical phenotype of the syndrome, however, these differences in the prevalence between the target populations are expected.

To avoid the bias of clinical referrals, the largest studies presented in Table $1^{38,40,41,47}$ screened broadly defined populations with mental retardation in an attempt to capture all males affected with the syndrome. Two of these studies ${ }^{38,41}$ broadened the definition to include persons receiving special education services regardless of mental retardation status. Although it is reasonable to assume that these studies have provided the most accurate estimates of the prevalence of the fragile X syndrome in the general population, some speculate that the true prevalence would be higher if 'high functioning' males were not placed in these target populations. ${ }^{48,49}$ Only the screening of a large population of consecutive newborns will solve this problem of complete ascertainment. ${ }^{50}$

\section{Full mutation and males: Other populations}

Little is known about the prevalence of the fragile $\mathrm{X}$ syndrome in other populations. Results of the few available studies suggest the prevalence may in fact differ across populations. For example, a report demonstrates that the majority of fragile $\mathrm{X}$ cases reported in Israel are of Tunisian Jewish descent. Given that most of the population of Israel is of Ashkenazi descent, investigators proposed that the prevalence of the fragile X syndrome is higher among Tunisian Jews compared with Caucasians by as much as 10 -fold. ${ }^{51}$ Also, investigators have noted the lack of large CGG repeats in Native American populations and have suggested a lower prevalence of the syndrome in these populations. ${ }^{52}$ Similarly, the Spanish Basque population has been reported to have lower prevalence of males with the fragile X syndrome of pure Basque origin in a mentally retarded population and a lower frequency of large CGG repeats compared with Caucasian populations of northern European descent. ${ }^{53,54}$ Finally, investigators in Nova Scotia reported an absence of fragile $\mathrm{X}$ cases among their mentally retarded population..$^{55}$

Although intriguing and suggestive, none of these studies in other populations were large and/or population-based. The only two population-based estimates for non-Caucasians were both conducted in African-derived populations. Elbaz et al. ${ }^{56}$ examined an Afro-Caribbean population in the French West Indies, and Crawford et al. ${ }^{38}$ examined an African American population in metropolitan Atlanta, Georgia, U.S.A. Surprisingly, both studies suggested that the point estimate in these admixed, African-derived populations is approximately 1 in 2,500 in the general population, which is higher than that observed in Caucasian populations (Table 1). Further studies are needed to explore this possible higher general population prevalence as the confidence intervals for both studies overlap with estimates in Caucasian populations of northern European descent.

\section{Full mutation and females}

Even less is known about the prevalence of the full mutation among females in the general population. Based on the prevalence of the full mutation among Caucasian males in the general population $(\sim 1$ in 4,000$)$ and the fact that only females can transmit the full mutation to their offspring, the expected prevalence among females affected with the fragile $\mathrm{X}$ syndrome is approximately 1 in 8,000 to 1 in 9,000 in the general population. In a voluntary screening of 8,462 women in Israel who had no family history of mental retardation, Pesso et al. ${ }^{57}$ identified one woman with the full mutation. Although the screening scheme described by Pesso et al. ${ }^{57}$ is not population-based, the point estimate for females in a Caucasian population is close to that expected.

\section{PREMUTATION}

The estimates for premutations available in the literature for males and females in the general population are summarized in Table 2. Because the frequency of premutations is close to zero, $95 \%$ confidence intervals were calculated using the equations recommended by Fleiss. ${ }^{58}$ For this review, we have chosen to define premutations as 61-200 repeats since these repeats are always unstable and have been found to expand to the full mutation. ${ }^{23,59}$ Premutations of smaller size are found in families with the fragile $\mathrm{X}$ syndrome; however, these smaller sized premutations found in the general population may or may not be unstable. Thus, the estimate of premutations in Table 2 represent the lower limits of premutation carriers.

\section{Premutation and males}

Similar to the data for the prevalence of the full mutation, most of the data on the prevalence of premutations were collected from Caucasian populations. Results from two large, population-based studies and several smaller studies suggest that the prevalence of premutations in males is approximately 1 in 1,000 in the general Caucasian population (Table 2).

\section{Premutation and females}

For females, recent large studies have established that the prevalence of premutation carriers is high, with point estimates ranging from 1 in 246 to 1 in 468 in the Caucasian general population. ${ }^{38,57,60-63}$ Curiously, the point estimates for the large studies derived from different populations in Israel ${ }^{57,61}$ differ, and the confidence intervals for both of these estimates barely overlap ( 1 in 271 vs. 1 in 468). Although the authors do not comment on the racial/ethnic background of these populations, it is worth noting that population differences that impact prevalence may exist as suggested in the full mutation data.

\section{DISEASE(S)}

The hallmark of the fragile X syndrome is mental retardation, which was noted as early as 1943 in a report of a large 
Crawford et al.

Table 1

Prevalence of the fragile X syndrome among males determined by DNA-based techniques (adapted from Warren and Sherman ${ }^{8}$ )

\begin{tabular}{|c|c|c|c|c|}
\hline \multirow[b]{2}{*}{ Country } & \multirow[b]{2}{*}{ Target population } & \multirow{2}{*}{$\begin{array}{l}\text { No. positive/ } \\
\text { No. tested }\end{array}$} & \multicolumn{2}{|c|}{ Estimated prevalence } \\
\hline & & & Target population (\%) & General population $(95 \% \mathrm{CI})$ \\
\hline U.K. (Wessex) $)^{41,121}$ & $\begin{array}{l}\text { SpEd population (ages 5-18 years), } \\
\text { unknown etiology }\end{array}$ & $20 / 3,738$ & SpEd: 0.5 & $1 / 5,530(1 / 8,992-1 / 4,007)$ \\
\hline \multirow[t]{2}{*}{ U.S.A. (Atlanta, Georgia) ${ }^{38,122}$} & $\begin{array}{l}\text { SpEd population (ages 7-10 years), } \\
\text { regardless of etiology }\end{array}$ & Caucasian: $4 / 1,572$ & Caucasian SpEd: 0.3 & $\begin{array}{l}\text { Caucasian: } 1 / 3,717(1 / 7,692- \\
\quad 1 / 1,869)\end{array}$ \\
\hline & & African-American: 3/752 & African-American SpEd: 0.4 & $\begin{array}{l}\text { African-American: } 1 / 2,545 \\
\quad(1 / 5,208-1 / 1,289)\end{array}$ \\
\hline Southwest Netherlands ${ }^{47}$ & $\begin{array}{l}\text { Schools and institutes for MR, unknown } \\
\text { etiology }\end{array}$ & $9 / 866$ & $\begin{array}{l}\text { Mild MR: } 2.0 \\
\text { Moderate/severe MR: } 2.4\end{array}$ & $1 / 6,045(1 / 9,981-1 / 3,851)$ \\
\hline $\begin{array}{l}\text { Hellenic population of Greece and } \\
\text { Cyprus }^{40}\end{array}$ & $\begin{array}{l}\text { Referred clinical population of idiopathic } \\
\text { MR }\end{array}$ & $8 / 611$ & MR: 1.3 & $1 / 4,246(1 / 16,440-1 / 1,333)$ \\
\hline Australia (Sydney) ${ }^{36,37}$ & Children with MR in SpEd & $10 / 472$ & $\begin{array}{l}\text { MR: } 2.1 \\
\text { Mild MR: } 0.6 \\
\text { Moderate/severe MR: } 5.4\end{array}$ & $1 / 4,350^{b}$ \\
\hline France $^{123}$ & $\begin{array}{l}\text { Children with DSM-IIIR classification of } \\
\text { MR }\end{array}$ & $10 / 403$ & $\begin{array}{l}\text { MR: } 2.5 \\
\text { Mild MR: } 1.4 \\
\text { Moderate/severe MR: } 3.6\end{array}$ & - \\
\hline U.S.A. (Baltimore, Maryland) ${ }^{46}$ & $\begin{array}{l}\text { Preschool children referred for language } \\
\text { delay }\end{array}$ & $1 / 379$ & Language delay: 0.3 & - \\
\hline China (mainland and Hong Kong) ${ }^{124}$ & $\begin{array}{l}\text { Persons with MR clinically referred or in } \\
\text { SpEd }\end{array}$ & $31 / 902^{a}$ & MR: 3.4 & - \\
\hline India (Delhi) $)^{125}$ & $\begin{array}{l}\text { Clinically referred children with MR, } \\
\text { unknown etiology }\end{array}$ & $19 / 360$ & MR: 5.3 & - \\
\hline Southern Häme, Finland ${ }^{126}$ & $\begin{array}{l}\text { Adult males ( }>16 \text { years) registered in the } \\
\text { Southern Häme Care Organization } \\
\text { with MR, unknown etiology }\end{array}$ & $6 / 344$ & MR: 1.7 & $1 / 4,400^{c}$ \\
\hline Finland ${ }^{45}$ & Clinically referred persons with MR & $15 / 305$ & MR: 4.9 & - \\
\hline U.S.A. (Colorado) ${ }^{127}$ & $\begin{array}{l}\text { Targeted "high-risk" children (ages 2-18 } \\
\text { years with MR, autism, LD, ADHD, } \\
\text { family history) in SpEd population }\end{array}$ & $1 / 299$ & SpEd: 0.3 & - \\
\hline Japan $^{128}$ & Institutionalized persons with $\mathrm{MR}$ & $8 / 298$ & MR: 2.7 & - \\
\hline Indonesia (primarily Javanese) ${ }^{129}$ & $\begin{array}{l}\text { Schools for mild developmental delay, no } \\
\text { cytogenetic abnormality }\end{array}$ & $5 / 262$ & Mild MR: 1.9 & - \\
\hline $\begin{array}{l}\text { Hellenic population of Greece and } \\
\text { Cyprus }{ }^{130}\end{array}$ & $\begin{array}{l}\text { Referred clinical population of idiopathic } \\
\text { MR }\end{array}$ & $4 / 257$ & $\begin{array}{l}\text { MR: } 1.6 \\
\text { Moderate/severe MR: } 2.9 \\
\text { Profound MR: } 3.6\end{array}$ & - \\
\hline Brazil131 & Schools for the mentally disabled & $5 / 256$ & $\begin{array}{l}\text { MR: } 2.0 \\
\text { Mild MR: } 2.3 \\
\text { Severe MR: } 1.6\end{array}$ & - \\
\hline$J^{J a p a n}{ }^{132}$ & $\begin{array}{l}\text { Males with MR or psychomotor } \\
\text { developmental delay, clinically referred }\end{array}$ & $2 / 256$ & MR: 0.8 & - \\
\hline Singapore $^{133}$ & $\begin{array}{l}\text { Children in schools for mild to severe } \\
\text { MR, unknown etiology }\end{array}$ & $5 / 254$ & MR: 2.0 & - \\
\hline Hong Kong ${ }^{134}$ & Persons with mild MR, unknown etiology & $1 / 243$ & Mild MR: 0.4 & - \\
\hline U.K. (Coventry) $)^{35,37,135}$ & Children with MR in institutions or SpEd & $6 / 219$ & $\begin{array}{l}\text { MR: } 2.7 \\
\text { Mild MR: } 1.3 \\
\text { Moderate/severe MR: } 6.7\end{array}$ & $1 / 4,090^{d}$ \\
\hline
\end{tabular}

-Continued

family with 11 mentally retarded males and two mildly retarded females. ${ }^{64}$ The clinical phenotype associated with the syndrome has since been widened to include a variety of cog- nitive, physical, and behavioral characteristics (reviewed in Mazzocco). ${ }^{65}$ Almost all males with the full mutation exhibit some clinical features of the fragile X syndrome. Also, most 
Fragile $X$ syndrome HuGE review

Table 1 (Continued)

\begin{tabular}{|c|c|c|c|c|}
\hline \multirow[b]{2}{*}{ Country } & \multirow[b]{2}{*}{ Target population } & \multirow[b]{2}{*}{ No. positive/No. tested } & \multicolumn{2}{|c|}{ Estimated prevalence } \\
\hline & & & Target population (\%) & General population $(95 \% \mathrm{CI})$ \\
\hline Chile ${ }^{136}$ & $\begin{array}{l}\text { Children in SpEd with MR of unknown } \\
\text { etiology; excluded profound MR }\end{array}$ & $4 / 214$ & MR: 1.9 & - \\
\hline Taiwan $^{137}$ & $\begin{array}{l}\text { Persons with MR of unknown etiology } \\
\text { enrolled in SpEd or private day-care centers }\end{array}$ & $4 / 206$ & $\begin{array}{l}\text { MR: } 1.9 \\
\text { Mild MR: } 3.8 \\
\text { Moderate/severe MR: } 0.8\end{array}$ & - \\
\hline Poland (Warsaw) ${ }^{42}$ & Males in institutions or SpEd with MR & $6 / 201$ & MR: 3.0 & $1 / 2,857-1 / 5,882^{e}$ \\
\hline Southwest Netherlands ${ }^{138}$ & $\begin{array}{l}\text { Clinically referred persons with } \mathrm{MR} \text { and no } \\
\text { known family history of fragile } \mathrm{X}\end{array}$ & $10 / 197$ & MR: 5.1 & - \\
\hline U.S.A. (New Mexico) $)^{139}$ & $\begin{array}{l}\text { Clinically referred persons with MR or } \\
\text { behavior disorders, unknown etiology }\end{array}$ & $10 / 188$ & $\begin{array}{l}\text { MR: } 3.7 \\
\text { LD: } 1.1 \\
\text { Hyperactivity/AD: } 0.5\end{array}$ & - \\
\hline Spain $^{140}$ & Persons with MR in SpEd & $11 / 182$ & MR: 6.0 & - \\
\hline U.K. $(\text { Wessex })^{39}$ & $\begin{array}{l}\text { SpEd population (ages 5-18 years), } \\
\text { unknown etiology }\end{array}$ & $4 / 180$ & SpEd: 2.2 & $1 / 8,918^{f}$ \\
\hline Spain $^{43}$ & $\begin{array}{l}\text { Children in SpEd or clinically referred with } \\
\text { MR of unknown etiology; no known family } \\
\text { history of MR }\end{array}$ & $5 / 180$ & MR: 2.7 & $1 / 6,200-1 / 8,200^{g}$ \\
\hline Turkey ${ }^{141}$ & $\begin{array}{l}\text { Clinically referred children with } \\
\text { developmental disability }\end{array}$ & $5 / 166$ & MR: 3.0 & - \\
\hline Guadeloupe, French West Indies ${ }^{56}$ & SpEd population, unknown etiology & $11 / 163$ & SpEd: 6.7 & $1 / 2,359(1 / 4,484-1 / 276)$ \\
\hline South Africa ${ }^{142,143}$ & $\begin{array}{l}\text { Institutionalized males (blacks) with } \\
\text { idiopathic MR }\end{array}$ & $9 / 148$ & $\begin{array}{l}\text { MR: } 6.1 \\
\text { Mild MR: } 4.2 \\
\text { Severe MR: } 7.8\end{array}$ & - \\
\hline U.K. ${ }^{144}$ & $\begin{array}{l}\text { Institutionalized males with learning } \\
\text { disabilities, unknown etiology }\end{array}$ & $1 / 138$ & LD: 0.7 & - \\
\hline U.K. (Oxfordshire $)^{44}$ & $\begin{array}{l}\text { Children in schools for moderate to severe } \\
\text { learning difficulties, unknown etiology }\end{array}$ & $4 / 103$ & MR: 3.9 & $1 / 4,130^{h}$ \\
\hline Thailand $^{145}$ & $\begin{array}{l}\text { Children with developmental delay or MR, } \\
\text { unknown etiology }\end{array}$ & $5 / 94$ & MR: 5.3 & - \\
\hline India (New Delhi) ${ }^{146,147}$ & $\begin{array}{l}\text { Institutionalized persons with MR with } \\
\text { unknown etiology that scored above } 40 \% \text { on } \\
\text { a fragile X checklist }\end{array}$ & $9 / 93$ & MR: 9.7 & - \\
\hline Spain ${ }^{53}$ & $\begin{array}{l}\text { Persons in institutions or SpEd with } \\
\text { idiopathic MR }\end{array}$ & $8 / 92$ & MR: 8.7 & - \\
\hline Brazil $^{148}$ & $\begin{array}{l}\text { Institutionalized persons with severe MR, } \\
\text { unknown etiology }\end{array}$ & $0 / 83$ & - & - \\
\hline Croatia ${ }^{149}$ & $\begin{array}{l}\text { Children clinically preselected for fragile X } \\
\text { DNA analysis on the basis of MR of } \\
\text { unknown etiology, a positive family history, } \\
\text { and at least on physical and/or behavioral } \\
\text { characteristic of the fragile X syndrome }\end{array}$ & $14 / 81$ & 17.3 & - \\
\hline Mexico $^{150}$ & $\begin{array}{l}\text { Children clinically referred with MR, } \\
\text { unknown etiology }\end{array}$ & $2 / 53$ & MR: 3.8 & - \\
\hline
\end{tabular}

SpEd, special education or special schools; MR, mental retardation; LD, learning disability; ADHD, attention-deficit/hyperactivity disorder; AD, attention deficit. ${ }^{a}$ Zhong et al. ${ }^{124}$ did not distinguish between males and females in the published manuscript. The numbers presented in Table 1 are derived from personal communication with Dr. Zhong.

${ }^{b}$ Turner et al. ${ }^{37}$ provided only a point estimate.

${ }^{c}$ Arvio et al. ${ }^{126}$ provided only a range on the basis of past cytogenetic and DNA-based diagnoses.

${ }^{d}$ Morton et al ${ }^{135}$ provided only a point estimate.

${ }^{e}$ Mazurczak et al. ${ }^{42}$ provided only a range, not a point estimate.

fJacobs et al. ${ }^{39}$ provided only a point estimate.

${ }^{g}$ Millan et al. ${ }^{43}$ provided a range, not a point estimate. Millan et al. ${ }^{43}$ also acknowledged that persons with mild MR might have been missed, so the range could be as high as $1 / 5,000-1 / 6,800$.

${ }^{h}$ Slaney et al. ${ }^{44}$ only provided a lower boundary, not a point estimate. 


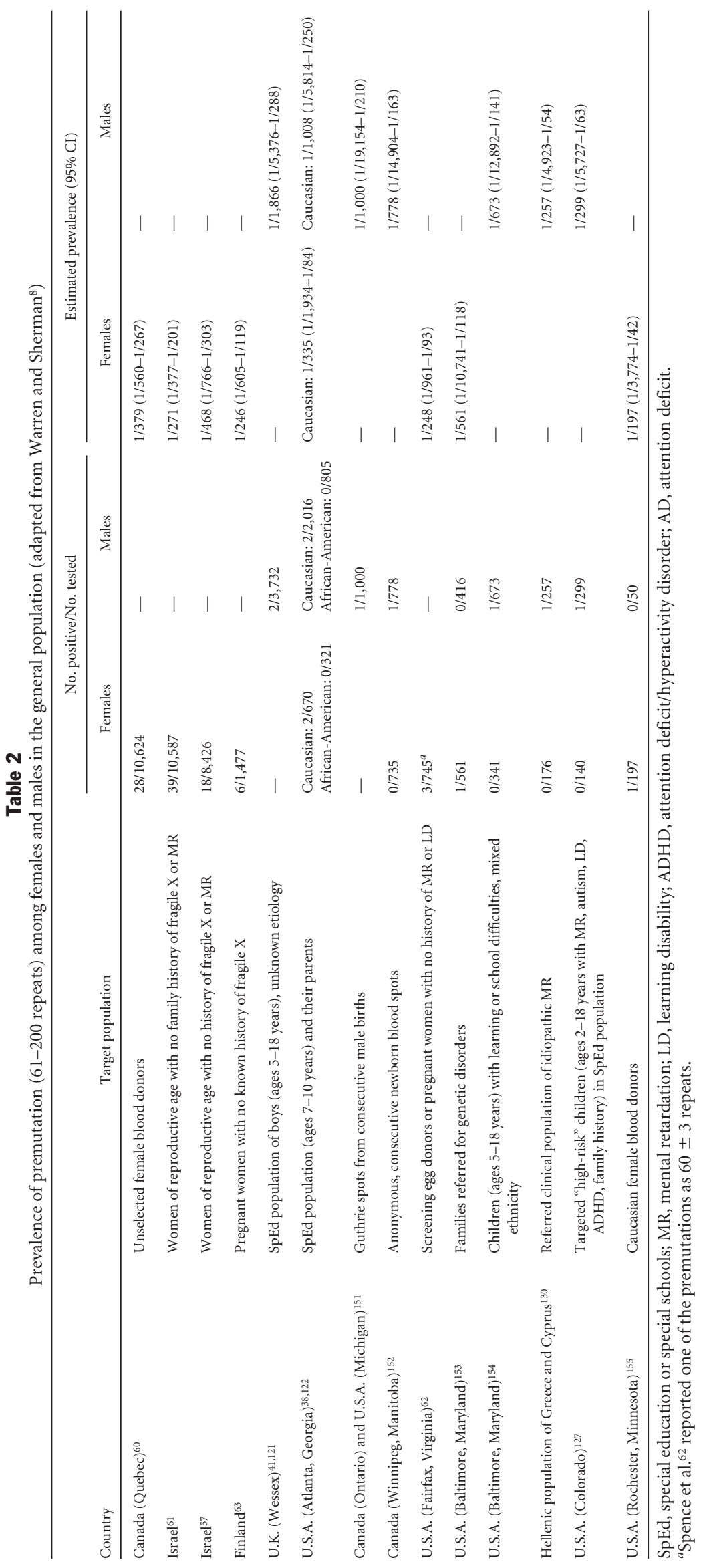


affected males do not reproduce, presumably due to the severity of mental retardation. With regard to cognitive function, affected males often exhibit developmental delay very early in childhood. By the age of 3 years, most males will test in the mentally retarded range. ${ }^{66}$ Ultimately, almost all males with the fragile $\mathrm{X}$ syndrome are mentally retarded, with severity ranging from profound (IQ $<20$ ) to mild mental retardation (IQ 50-70), with most being moderately retarded (IQ 40-54) (reviewed in Hagerman). ${ }^{67}$ Physically, adult males often have a long narrow face, prominent ears, a prominent jaw, and macroorchidism (reviewed in Hagerman). ${ }^{67}$ Other common physical features include a high arched palate, hyperextensible finger joints, double jointed thumbs, single palmar crease, hand calluses, velvet-like skin, flat feet, and mitral valve prolapse (reviewed in Warren and Sherman). ${ }^{8}$ Males with the fragile X syndrome also tend to exhibit behavioral features such as hyperactivity, social anxiety, perseverative speech and language, tactile defensiveness, stereotypies (e.g., hand-flapping), and hand biting (reviewed in Hagerman). ${ }^{67}$ Autistic-like behavior is also described in these males, with as many as $25 \%$ of males with the fragile $\mathrm{X}$ syndrome meeting the diagnostic criteria for autism. ${ }^{68}$ The association of fragile $\mathrm{X}$ with autism, however, is not clear because the proportion of males with the fragile $\mathrm{X}$ syndrome meeting the diagnostic criteria for autism seems to diminish with age. ${ }^{68}$

Compared with males, females with the full mutation are often less affected, presumably because of X-inactivation. ${ }^{69,70}$ Approximately $30 \%$ to $50 \%$ of females with the full mutation have an IQ of $<70$, and $50 \%$ to $70 \%$ of females with the full mutation have an IQ of $<85$ e.g. ${ }^{71}$ Unlike males with the full mutation, females with the full mutation do not typically have reduced reproductive fitness. Thus, these women are at-risk of transmitting the full mutation to their offspring.

\section{ASSOCIATIONS}

Traditionally, persons with premutations were considered clinically normal. However, behavior and cognitive studies of both males and females with the premutation suggest that there may be a mild, measurable phenotype related to this repeat size, although there is also evidence to the contrary. ${ }^{72-79} \mathrm{At}$ the molecular level, recent experiments using more sensitive techniques than previously employed suggest that males with large premutation alleles (100-199 repeats) have fewer FMRPpositive cells and an elevated FMR1 mRNA level. ${ }^{80}$ Furthermore, experiments also suggest that the decrease of FMRP and the increase of FMR1 transcript are related to the increasing size of the repeat. ${ }^{81}$ These results suggest a mechanism in which the lower translational efficiency presumedly caused by the large repeat is being compensated by the increase in transcription. ${ }^{80,81}$ Alternatively, the expanded CGG repeat could lead to a proportionally more open promoter conformation and enhanced transcription..$^{81,82}$ What behavioral or cognitive phenotypic effect, if any, these mechanisms have on the individual with the premutation allele is unclear.
The most convincing evidence of a phenotype among female premutation carriers is the $\sim 21 \%$ (95\% confidence interval: $15 \%$ to $27 \%$ ) who experience premature ovarian failure (POF), compared with $1 \%$ in the general population..$^{83}$ Whereas the mean age of menopause is 51 years, women with POF experience the cessation of menses before the age of 40 . The molecular basis of this phenotype remains unknown. Because full mutation female carriers are not at elevated risk for POF, compared with premutation carriers, the lack of FMRP does not seem to be responsible for POF. The transcript with a large repeat has been suggested to somehow cause the POF phenotype, as this transcript is absent among persons with the full mutation. The exact molecular mechanism of the altered transcript causing POF remains to be elucidated.

\section{INTERACTIONS}

No interactions with environmental factors or other genes have been identified for the fragile X syndrome. However, such interactions may be possible as witnessed by the range in clinical severity of fully methylated, full mutation males and females, even among monozygotic twins. ${ }^{84-86}$ Among repeatsize or methylation mosaic males and females, variability in IQ can be partially explained by the variability in FMRP levels. ${ }^{87}$ However, neither features of FMR1 nor its gene product FMRP can account for the majority of the variability among fully methylated, full mutation males. For example, size of the methylated full mutation is not correlated with IQ or related to the occurrence other specific characteristics of affected males such as attention-deficit/hyperactivity disorder. ${ }^{88}$ Also, while the low but measurable level of FMRP seems to be related to level of development among affected males, it does not seem to be related to the rate of development or to the expression of autism. ${ }^{89} \mathrm{In}$ fact, the co-occurrence of autistic behavior and the fragile X syndrome more accurately predicts developmental status than does the level of FMRP, ${ }^{89}$ possibly suggesting the existence of additional factors involved in the fragile $\mathrm{X}$ phenotype.

Interactions affecting CGG repeat stability may also exist. Expansion and resulting size of the premutation are more similar among families than between families, and risk for expansion of premutations is greater among families with affected persons compared with the general population. ${ }^{23,26}$ Supportive evidence for an unidentified 'familial' factor can be found in a study that showed full mutation repeat sizes are more similar among siblings than among unrelated patients..$^{90}$ Finally, studies examining repeat size variation in sperm suggest that only a small portion of the variance can be explained by factors already identified. ${ }^{91,92}$ Identification and description of new factors will lead to a better understanding of which families are at risk of developing a hyperexpanding allele.

\section{LABORATORY TESTS}

The Quality Assurance Subcommittee of the American College of Medical Genetics Laboratory Practice Committee has 
recently published technical standards and guidelines for fragile $\mathrm{X}$ syndrome testing. ${ }^{24}$ According to the subcommittee, DNA-based tests that determine the size of the fragile X CGG repeat are considered diagnostic and are 99\% sensitive and $100 \%$ specific. ${ }^{24}$ These DNA-based tests are also applicable for prenatal diagnosis in both amniotic fluid cells and chorionic villus samples (CVS). However, all DNA-based tests for the fragile $\mathrm{X}$ syndrome have important caveats that impact the interpretation of the test, most of which are reviewed below. For a more comprehensive checklist, please refer to the standards and guidelines published by the Quality Assurance Subcommittee. ${ }^{24}$

The most popular and accepted method for DNA-based testing for the expanded CGG repeat is the Southern blot. Many different restriction enzymes can be used in combination to determine both expansion (EcoRI, PstI, BglII, HindIII, $B c l I$ ) and methylation (SacII, BssHII, EagI, BstZI) status for an individual (for a review, see Warren and Sherman, and Murray et al. $)^{8,93}$ Methylation status is particularly useful for distinguishing between borderline premutation and full mutation alleles (200-230 repeats). ${ }^{24}$ Methylation sensitive enzymes can also describe the degree of methylation of the full mutation allele for both males and females as well as the X-inactivation pattern for females. However, neither of these measures can be used to predict the degree of mental retardation status for either sex. ${ }^{24}$ The main disadvantage of the Southern blot is that it requires a large amount of DNA and is laborious, both of which are features that prevent the rapid and inexpensive screening of large populations. Because of these limitations, other diagnostic tests based on DNA and protein properties of the fragile $\mathrm{X}$ syndrome have been developed for fragile $\mathrm{X}$ screening.

New DNA diagnostic tests have concentrated on the use of the polymerase chain reaction (PCR). Many different PCR protocols have been developed for the fragile X CGG repeat, with different degrees of amplification abilities and sizing accuracies. Regardless of the variations in protocol, compared with Southern blots, the PCR test is inexpensive, automated, and fast. Also, PCR can be performed on very small amounts of DNA, making collection of the samples relatively painless and convenient for the patients. The disadvantage of PCR is that the test results may not be straightforward for several reasons. The amplification of large repeats is difficult, especially in the presence of a second, smaller repeat. For many PCR protocols, the DNA fragment with the expanded repeat does not amplify. This is especially problematic for females and persons with repeat-size mosaicism who could appear to have a single, normal repeat size. To avoid these false negatives, many screening programs follow-up by Southern blot any sample that fails to amplify by PCR and any female who appears to be homozygous. This strategy could potentially produce a false-negative result for persons who are normal/full mutation mosaic; however, few data exist to suggest that this occurs frequently.

Most DNA-based methods can distinguish between premutations and full mutations. Because of ethical issues in identifying asymptomatic carriers, some proposed screening strate- gies are designed to identify only affected persons. Also, affected persons with point mutations and deletions would not be identified because the sequencing of FMR1 is not routinely practiced for screening strategies. ${ }^{94}$ For the fragile X syndrome, affection status depends not only on the expansion of the repeat, but the subsequent lack of FMRP as well. The development of antibodies against FMRP has made screening possible on the basis of affection status only.9,21 In this protein-based assay, the percentage of FMRP detected in lymphocytes from blood smears is used to determine affection status. ${ }^{95-97}$ Typically, fewer than $40 \%$ of the lymphocytes from males with the fragile X syndrome have detectable amounts of FMRP. ${ }^{96}$ This protein-based test has recently been adapted for hair $\operatorname{root}^{98,99}$ and prenatal ${ }^{100,101}$ samples. Although promising, this technique cannot accurately identify affected females. ${ }^{87}$

\section{POPULATION TESTING}

\section{Syndrome screening}

No large, routine programs exist to screen for the fragile $\mathrm{X}$ syndrome. As a result, most cases are diagnosed through a referral for testing. In 1994, a working group for the American College of Medical Genetics published guidelines in making referrals for fragile $\mathrm{X}$ testing. ${ }^{102}$ These include testing any person with unexplained mental retardation, developmental delay, or autism, especially if physical or behavioral characteristics commonly associated with the fragile $\mathrm{X}$ syndrome are evident. The working group also recommends testing on the basis of a family history of unexplained mental retardation. On the basis of these recommendations, $1 \%$ to $2 \%$ of samples referred for molecular testing for the fragile X syndrome are actually positive for the syndrome. ${ }^{103-105}$

Beyond the referral system, investigators in the United Kingdom, United States, and Netherlands have employed active screening systems geared toward school-aged children with mental retardation or other learning difficulties, regardless of family history (Table 1). ${ }^{38,41,47}$ The decision for fragile $\mathrm{X}$ testing among these nonclinically referred populations differed among the studies. For example, the studies in the United Kingdom and Netherlands tested children with mental retardation or learning difficulties of unknown etiology, ${ }^{41,47}$ and the study in the United States screened all eligible children with parental consent regardless of etiology. ${ }^{38}$ Despite differences in the decision to test, all three studies identified the fragile $\mathrm{X}$ syndrome in school-aged children previously undiagnosed.

Identification of new cases of the fragile $\mathrm{X}$ syndrome among school-aged children suggests that the syndrome is not being diagnosed through the referral system. ${ }^{106}$ Despite the combination of mental retardation and specific physical and behavioral characteristics associated with the fragile X syndrome (see Disease section), the development of clinical checklists designed to identify children for fragile X screening has been hampered by several factors. First, the physical characteristics in affected adult males may not be seen in young affected males. ${ }^{107}$ Macroorchidism is also often absent until the onset of puberty in males. Also, some of the facial features, such as the 
prominent jaw, may be racial- or ethnic-specific. ${ }^{108}$ Second, the degree of mental retardation and developmental delay among affected males varies widely. This variation in cognitive ability greatly affects the timing of diagnosis. Often, males with severe mental retardation are tested for the fragile $\mathrm{X}$ syndrome much earlier in childhood compared with males with moderate or mild mental retardation. ${ }^{109,110}$

\section{Carrier screening}

In this section, "carrier screening" refers to identifying women with premutation or full mutation alleles because both are at risk of transmitting a full mutation to their offspring in the next generation. The working group for the American College of Medical Genetics currently does not recommend population carrier screening. ${ }^{102}$ In the United States, populationbased carrier screening programs for the fragile X syndrome targeting women of reproductive age do not exist. The literature contains reports of smaller screening studies based on self-referral or a family history of mental retardation. One such program at the New York State Institute for Basic Research screened over a 3-year period 344 pregnant women with family histories of mental retardation. ${ }^{111}$ Among these women, two had full mutations and four had premutations (defined as $>55$ repeats). Another program at the Genetics \& IVF Institute in Fairfax, Virginia, offered fragile X carrier screening to women on a self-pay basis. ${ }^{62,112}$ Most women were referred to the clinic because of their advanced reproductive age. From December 1993 through June 1995, 3,345 women were offered testing, and 668 accepted (21\%). Most (69\%) of these women did not have family histories of mental retardation. Among these women, three premutation carriers (60-199 repeats) were identified. ${ }^{62}$ In a third study conducted at the Center for Obstetric Research at the University of Alabama at Birmingham during 1994-1998, 263 (2.1\%) of 12,349 pregnant women reported a family history of mental retardation and underwent carrier testing, ${ }^{113}$ and no full mutations or premutations were identified.

Unlike the screening studies performed in the United States, investigators in Finland have implemented a large, population-based carrier-screening program. The program implemented by the Kuopio University Hospital in Finland offered an FMR1 gene test free of charge to all pregnant women seeking prenatal care from July 1995 until December 1996. ${ }^{63}$ According to Ryynanen et al., ${ }^{63}$ almost all pregnant women in Finland seek prenatal care and are registered in antenatal clinics during the $6^{\text {th }}$ through $10^{\text {th }}$ weeks of pregnancy because this registration is required for maternity allowance provided by the state. Among women without family histories of the fragile $\mathrm{X}$ syndrome, 1,477 (85\%) elected genetic testing. Of these women, six were identified as premutation carriers (60-199 repeats) and all six women elected prenatal testing. The program has since screened an additional 1,358 women through December 1997. Six more women with the premutation allele were identified, and all six elected prenatal diagnosis. ${ }^{114}$ The program has also expanded to offer an FMR1 genetic test to pregnant women undergoing invasive prenatal testing for ad- vanced maternal age or history of a trisomy pregnancy. In this expanded program, 241 (80\%) of the 302 women offered the test consented, and one woman was identified as a premutation carrier. ${ }^{114}$

As in Finland, carrier testing is also widely employed and accepted in Israel. At least three groups have published results obtained from their large screening programs. Unlike the program in Finland, these programs offer the test on a self-pay basis and rely on either a self-referral or physician referral for testing. In one published report, the Rabin Medical Center screened 10,587 women who were self-referred and had no family histories of mental retardation during 1995-1998. ${ }^{61}$ Women identified as carriers were offered prenatal testing free of charge as instructed by the Israeli Ministry of Health. A total of 39 women were identified as premutation carriers (61-200 repeats), and all elected prenatal diagnosis. ${ }^{61}$ In a second report, the Genetic Institute of the Tel Aviv Sourasky Medical Center offered an FMR1 genetic test to 9,660 women during September 1994 through October 1998. ${ }^{26}$ A total of 38 premutation carriers (60-200 repeats) were identified, and all of these women consented to prenatal diagnosis. ${ }^{26}$ Finally, during January 1994 through March 1999, the Danek-Gertner Institute of Human Genetics screened 8,426 women of reproductive age who had no family histories of the fragile $\mathrm{X}$ syndrome or mental retardation. ${ }^{57}$ Among these women, 18 were identified as premutation carriers (61-199 repeats), and one was identified as a full mutation carrier ( $>200$ repeats).

Compared with preconceptional or prenatal screening described above, the most employed strategy for fragile X carrier screening is cascade screening of families identified through an affected proband. This method of screening relies heavily on both identification of the index case and communication among relatives. Using this strategy, the Fragile X Program of the Prince of Wales Children's Hospital in New South Wales, Australia, has identified and counseled 195 families with the fragile X syndrome (or X-linked mental retardation with macroorchidism) since the late 1960s. ${ }^{115}$ Follow-up of 44 women identified as carriers by DNA testing who became pregnant during 1990-1993 revealed that 34 (77\%) elected prenatal testing. Also, follow-up of the reproductive decisions and outcomes of carrier women demonstrated a 10-fold decline in the birth incidence of males affected with the fragile X syndrome, reflecting both a reduction in the birth rate and an increase in termination of affected pregnancies. ${ }^{115}$

\section{Gaps in research related to screening}

The Task Force on Newborn Screening suggests that a disease or condition must meet several criteria to be considered for inclusion in newborn screening programs. The fragile $\mathrm{X}$ syndrome arguably meets many of these criteria. ${ }^{116}$ Specifically, based on its morbidity and prevalence, the fragile X syndrome is an important public health problem. Approximately $99 \%$ of cases diagnosed to date are caused by a single, inherited mutation, making the fragile $\mathrm{X}$ syndrome particularly amenable to DNA-based testing for an accurate diagnosis. ${ }^{24}$ Furthermore, preliminary studies suggest that case finding and carrier 
screening may be economically feasible. ${ }^{117,118}$ Finally, although few data exist for the United States, data in Finland and Israel (see, Carrier screening section) suggest that the fragile $\mathrm{X}$ test is acceptable.

Although testing for the fragile $\mathrm{X}$ syndrome may be feasible and economical, it does not meet several other key criteria for screening in the public health arena. One crucial gap in research is the lack of a cure or effective treatment available for persons with the disorder. This research gap, however, will be difficult to fill. While children with the fragile X syndrome are eligible for early invention services, the effectiveness of these services cannot be proven unless infants are diagnosed with the fragile X syndrome soon after birth. ${ }^{119}$ A second gap, at least in the United States, is the lack of general consensus for the appropriate time to screen. Newborn screening will identify affected infants that are eligible for early intervention services. However, identification of an affected person will also identify at-risk families. Although these identified families could benefit from genetic counseling, newborn screening is neither ideal nor designed for identifying most at-risk families for the fragile X syndrome in the general population. ${ }^{120}$ Finally, many other issues, including educating health-care professionals and the public about the syndrome, assessing the psychological impact of carrier status, and maintaining families' privacy, should be thoroughly researched and adequately resolved before implementation of any type of routine screening for the fragile $\mathrm{X}$ syndrome in the general population.

\section{Acknowledgment} SLS).

This work was supported in part by NIH R01 grant HD29909 (to

\section{References}

1. Ashley CT, Sutcliffe JS, Kunst CB, Leiner HA, Eichler EE, Nelson DL, Warren ST. Human and murine FMR-1: alternative splicing and translational initiation downstream of the CGG repeat. Nat Genet 1993;4:244-251.

2. Eichler EE, Richards S, Gibbs RA, Nelson DL. Fine structure of the human FMR1 gene. Hum Mol Genet 1993;3:684-685.

3. Verkerk AJM, Pieretti M, Sutcliffe JS, Fu Y-H, Kuhl DPA, Pizzuti A, Reiner O, Richards S, Victoria MF, Zhang F, Eussen BE, van Ommen G-JB, Blonden LAJ, Riggins GJ, Chastain JL, Kunst CB, Galjaard H, Caskey CT, Nelson DL, Oostra BA, Warren ST. Identification of a gene (FMR-1) containing a CGG repeat coincident with a breakpoint cluster region exhibiting length variation in fragile $\mathrm{X}$ syndrome. Cell 1991;65:905-914.

4. Siomi MC, Siomi H, Sauer WH, Srinivasan S, Nussbaum RL, Dreyfuss G. FXR1, an autosomal homolog of the fragile X mental retardation gene. EMBO J 1995;14: 2401-2408.

5. Price DK, Zhang F, Ashley CT, Warren ST. The chicken FMR1 gene is highly conserved with a CCT 5 '-untranslated repeat and encodes an RNA-binding protein. Genomics 1996;31:3-12.

6. Wan L, Dockendorff TC, Jongens TA, Dreyfuss G. Characterization of dFMR1, a Drosophila melanogaster homolog of the fragile $\mathrm{X}$ mental retardation protein. Mol Cell Biol 2000;20:8536-8547.

7. Hinds HL, Ashley CT, Sutcliffe JS, Nelson DL, Warren ST, Housman DE, Schalling M. Tissue specific expression of FMR-1 provides evidence for a functional role in fragile X syndrome. Nat Genet 1993;3:36-43.

8. Warren ST, Sherman SL. The fragile X syndrome. In: Scriver CR, Beaudet AL, Sly WS, editors. Valle D, The metabolic and molecular basis of inherited disease. New York: McGraw-Hill, 2001:1257-1289.

9. Siomi H, Siomi MC, Nussbaum RL, Dreyfuss G. The protein product of the fragile X gene, FMR1, has characteristics of an RNA-binding protein. Cell 1993;74:291298.

10. Siomi MC, Zhang Y, Siomi H, Dreyfuss G. Specific sequences in the fragile X syndrome protein FMR1 and the FXR proteins mediate their binding to $60 \mathrm{~S}$ ribo- somal subunits and the interactions among them. Mol Cell Biol 1996;16:38253832

11. Tamanini F, Willemsen R, van Unen L, Bontekoe C, Galjaard H, Oostra BA, Hoogeveen AT. Differential expression of FMR1, FXR1 and FXR2 proteins in human brain and testis. Hum Mol Genet 1997;6:1315-1322.

12. Tamanini F, Bontekoe C, Bakker CE, van Unen L, Anar B, Willemsen R, Yoshida M, Galjaard H, Oostra BA, Hoogeveen AT. Different targets for the fragile X-related proteins revealed by their distinct nuclear localizations. Hum Mol Genet 1999; 8:863-869.

13. Tamanini F, van Unen L, Bakker C, Sacchi N, Galjaard H, Oostra BA, Hoogeveen AT. Oligomerization properties of fragile-X mental-retardation protein (FMRP) and the fragile-X-related proteins FXR1P and FXR2P. Biochem J 1999;343:517523.

14. Laggerbauer B, Ostareck D, Keidel EM, Ostareck-Lederer A, Fischer U. Evidence that fragile $\mathrm{X}$ mental retardation protein is a negative regulator of translation. Hum Mol Genet 2001;10:329-338.

15. Eberhart DE, Malter HE, Feng Y, Warren ST. The fragile X mental retardation protein is a ribonucleoprotein containing both nuclear localization and nuclear export signals. Hum Mol Genet 1996;5:1083-1091.

16. Corbin F, Bouillon M, Fortin A, Morin S, Rousseau F, Khandjian EW. The fragile $\mathrm{X}$ mental retardation protein is associated with poly $(\mathrm{A})+$ mRNA in actively translating polyribosomes. Hum Mol Genet 1997;6:1465-1472.

17. Tamanini F, Meijer N, Verheij C, Willems PJ, Galjaard H, Oostra BA, Hoogeveen AT. FMRP is associated to the ribosomes via RNA. Hum Mol Genet 1996;5:809813.

18. Ceman S, Brown V, Warren ST. Isolation of an FMRP-associated messenger ribonucleoprotein particle and identification of nucleolin and the fragile X-related proteins as components of the complex. Mol Cell Biol 1999;19:7925-7932.

19. Bardoni B, Schenck A, Mandel J. A novel RNA-binding nuclear protein that interacts with the fragile X mental retardation (FMR1) protein. Hum Mol Genet 1999; 8:2557-2566.

20. Devys D, Lutz Y, Rouyer N, Bellocq J-P, Mandel J-L. The FMR-1 protein is cytoplasmic, most abundant in neurons and appears normal in carriers of a fragile $\mathrm{X}$ premutations. Nat Genet 1993;4:335-340.

21. Verheij C, Bakker CE, de GraaffE, Keulemans J, Willemsen R, Verkerk AJ, Galjaard $\mathrm{H}$, Reuser AJ, Hoogeveen AT, Oostra BA. Characterization and localization of the FMR-1 gene product associated with fragile X syndrome. Nature 1993;363:722724.

22. Feng Y, Gutekunst CA, Eberhart DE, Yi H, Warren ST, Hersch SM. Fragile X mental retardation protein: nucleocytoplasmic shuttling and association with somatodendritic ribosomes. J Neurosci 1997;17:1539-1547.

23. Nolin SL, Lewis FA, Ye LL, Houck GE, Glicksman AE, Limprasert P, Li SY, Zhong N, Ashley AE, Feingold E, Sherman SL, Brown WT. Familial transmission of the FMR1 CGG repeat. Am J Hum Genet 1996;59:1252-1261.

24. Maddalena A, Richards CS, McGinniss MJ, Brothman A, Desnick RJ, Grier RE, Hirsch B, Jacky P, McDowell GA, Popovich B, Watson M, Wolff DJ. Technical standards and guidelines for fragile X: the first of a series of disease-specific supplements to the standards and guidelines for Clin Genet Laboratories of the American College of Medical Genetics. Genet Med 2001;3:200-205.

25. Ashley-Koch AE, Robinson H, Glicksman AE, Nolin SL, Schwartz CE, Brown WT, Turner G, Sherman SL. Examination of factors associated with instability of the FMR1 CGG repeat. Am J Hum Genet 1998;63:776-785.

26. Geva E, Yaron Y, Shomrat R, Ben-Yehuda A, Zabari S, Peretz H, Naiman T, Yeger $\mathrm{H}$, Orr-Urtreger A. The risk of fragile X premutation expansion is lower in carriers detected by general prenatal screening than in carriers from known fragile $\mathrm{X}$ families. Genet Testing 2000;4:289-292.

27. Malter HE, Iber JC, Willemsen R, de Graaff E, Tarleton JC, Leisti J, Warren ST, Oostra BA. Characterization of the full fragile X syndrome mutation in fetal gametes. Nat Genet 1997;15:165-169.

28. Moutou C, Vincent MC, Biancalana V, Mandel JL. Transition from premutation to full mutation in fragile X syndrome is likely to be prezygotic. Hum Mol Genet 1997;6:971-979.

29. Reyniers E, Vits L, De Boulle K, Van Roy B, Van Velzen D, de Graaff E, Verkerk AJ, Jorens HZ, Darby JK, Oostra B. The full mutation in the FMR-1 gene of male fragile X patients is absent in their sperm. Nat Genet 1993;4:143-146.

30. Sutcliffe JS, Nelson DL, Zhang F, Pieretti M, Caskey CT, Saxe D, Warren ST. DNA methylation represses FMR-1 transcription in fragile X syndrome. Hum Mol Genet 1992;1:397-400.

31. Coffee B, Zhang F, Warren ST, Reines D. Acetylated histones are associated with FMR1 in normal but not fragile X syndrome cells. Nat Genet 1999;22:98-101.

32. Pieretti M, Zhang F, Fu YH, Warren ST, Oostra BA, Caskey CT, Nelson DL. Absences of expression of the FMR-1 gene in fragile X syndrome. Cell 1991;66:817822. 
33. Fu Y-H, Kuhl DPA, Pizzuti A, Pieretti M, Sutcliffe JS, Richards S, Verkerk AJM, Holden JH, Fenwick RG, Warren ST, Oostra BA, Nelson DL, Caskey CT. Variation of the CGG repeat at the fragile $\mathrm{X}$ site results in genetic instability: resolution of the Sherman paradox. Cell 1991;67:1047-1058.

34. Sutherland GR. Fragile sites on human chromosomes: demonstration of their dependence on the type of tissue culture medium. Science 1977;197:265-266.

35. Webb T, Bundey S, Thake J, Todd A. The frequency of the fragile X chromosome among schoolchildren in Coventry. J Med Genet 1986;23:396-399.

36. Turner G, Robinson H, Laing S, Purvis-Smith S. Preventive screening for the fragile X syndrome. N Engl J Med 1986;315:607-609.

37. Turner G, Webb T, Robinson H. Prevalence of fragile X syndrome. Am J Med Genet 1996;64:196-197.

38. Crawford DC, Meadows KL, Newman JL, Taft LF, Scott E, Leslie M, Shubek L, Holmgreen P, Yeargin-Allsopp M, Boyle C, Sherman SL. Prevalence of the fragile X syndrome in African Americans (submitted).

39. Jacobs PA, Bullman H, Macpherson J, Youings S, Rooney V, Watson A, Dennis NR. Population studies of the fragile X: a molecular approach. J Med Genet 1993;30: 454-459.

40. Patsalis PC, Sismani C, Hettinger JA, Boumba I, Georgiou I, Stylianidou G, Anastasiadou V, Koukoulli R, Pagoulatos G, Syrrou M. Molecular screening of fragile X (FRAXA) and FRAXE mental retardation syndromes in the Hellenic population of Greece and Cyprus: incidence, genetic variation, and stability. Am J Med Genet 1999;84:184-190.

41. Youings SA, Murray A, Dennis N, Ennis S, Lewis C, McKechnie N, Pound M, Sharrock A, Jacobs P. FRAXA and FRAXE: the results of a five year survey. J Med Genet 2000;37:415-421.

42. Mazurczak T, Bocian E, Milewski M, Obersztyn E, Stanczak H, Bal J, Szamotulska K, Karwacki MW. Frequency of Fra X syndrome among institutionalized mentally retarded males in Poland. Am J Med Genet 1996;64:184-186.

43. Millan JM, Martinez F, Cadroy A, Gandia J, Casquero M, Beneyto M, Badia L, Prieto F. Screening for FMR1 mutations among the mentally retarded: prevalence of the fragile X syndrome in Spain. Clin Genet 1999;56:98-99.

44. Slaney SF, Wilkie AOM, Hirst MC, Charlton R, McKinley M, Pointon J, Christodoulou Z, Huson SM, Davies KE. DNA testing for fragile X syndrome in schools for learning difficulties. Arch Dis Child 1995;72:33-37.

45. von Koskull H, Gahmberg N, Salonen R, Salo A, Peippo M. FRAXA locus in fragile $\mathrm{X}$ diagnosis: family studies, prenatal diagnosis, and diagnosis of sporadic cases of mental retardation. Am J Med Genet 1994;51:486-489.

46. Mazzocco MMM, Myers GF, Hamner JL, Panoscha R, Shapiro BK, Reiss AL. The prevalence of the FMR1 and FMR2 mutations among preschool children with language delay. J Pediatr 1998;132:795-801.

47. de Vries BBA, van den Ouweland AMW, Mohkamsing S, Duivenvoorden HJ, Mol E, Gelsema K, van Rijn M, Halley DJJ, Sandkuijl LA, Oostra BA, Tibben A, Niermeijer MF, Collaborative Fragile X Study Group. Screening and diagnosis for the fragile X syndrome among the mentally retarded: an epidemiological and psychological survey. Am J Hum Genet 1997;61:660-667.

48. Harris SW, Hagerman RJ. Fragile X. syndrome: new developments. Curr Opin Psychiatry 1999;12:573-578.

49. Hagerman R. Prevalence of fragile X syndrome. 2000. Available at http://www.fragilex.org/testing/prevalence/prevalence.htm

50. Neri G, Chiurazzi P. Fragile X syndrome screening: a current opinion. Community Genet 2000;3:38-40.

51. Falik-Zaccai TC, Shachak E, Yalon M, Lis Z, Borochowitz Z, Macpherson JN, Nelson DL, Eichler EE. Predisposition to the fragile X syndrome in Jews of Tunisian descent is due to the absence of AGG interruptions on a rare Mediterranean haplotype. Am J Hum Genet 1997;60:103-112.

52. Kunst CB, Zerylnick C, Karickhoff L, Eichler E, Bullard J, Chalifoux M, Holden JJ, Torroni A, Nelson DL, Warren ST. FMR1 in global populations. Am J Hum Genet 1996;58:513-522.

53. Arrieta I, Criado B, Martinez B, Telez M, Nunez T, Penagarikano O, Ortega B, Lostao CM. A survey of fragile $\mathrm{X}$ syndrome in a sample from Spanish Basque country. Ann Genet 1999;42:197-201.

54. Arrieta I, Gil A, Nunez T, Elez M, Artinez B, Criado B, Stao C. Stability of the FMR1 CGG repeat in a Basque sample. Hum Biol 1999;71:55-68.

55. Beresford RG, Tatlidil C, Riddell DC, Welch JP, Ludman MD, Neumann PE, Greer WL. Absence of fragile X syndrome in Nova Scotia. J Med Genet 2000;37:77-79.

56. Elbaz A, Suedois J, Duquesnoy M, Beldjord C, Berchel C, Merault G. Prevalence of fragile X syndrome and FRAXE among children with intellectual disability in a Caribbean island, Guadeloupe, French West Indies. J Intellect Disabil Res 1998;42: 81-89.

57. Pesso R, Berkenstadt M, Cuckle H, Gak E, Peleg L, Frydman M, Barkai G. Screening for fragile X syndrome in women of reproductive age. Prenat Diagn 2000;20:611614.
58. Fleiss JL. An introduction to applied probability. In: Statistical methods for rates and proportions. New York: John Wiley and Sons, 1981:1-18.

59. Murray A, Macpherson JN, Pound MC, Sharrock A, Youings SA, Dennis NR, McKechnie N, Linehan P, Morton NE, Jacobs PA. The role of size, sequence and haplotype in the stability of FRAXA and FRAXE alleles during transmission. Hum Mol Genet 1997;6:173-184.

60. Rousseau F, Rouillard P, Morel M-L, Khandjian EW, Morgan K. Prevalence of carriers of premutation-size alleles of the FMR1 gene-and implications for the population genetics of the fragile X syndrome. Am J Hum Genet 1995;57:10061018

61. Drasinover V, Ehrlich S, Magal N, Taub E, Libman V, Shohat T, Halpern GJ, Shohat M. Increased transmission of intermediate alleles of the FMR1 gene compared with normal alleles among female heterozygotes. Am J Med Genet 2000;93: 155-157.

62. Spence WC, Black SH, Fallon L, Maddalena A, Cummings E, Menapace-Drew G, Bick DP, Levinson G, Schulman JD, Howard-Peebles PN. Molecular fragile X screening in normal populations. Am J Med Genet 1996;64:181-183.

63. Ryynanen M, Heinonen S, Makkonen M, Kajanoja E, Mannermaa A, Pertti K. Feasibility and acceptance of screening for fragile X mutations in low-risk pregnancies. Eur J Hum Genet 1999;7:212-216.

64. Martin JP, Bell J. A pedigree of mental defect showing sex-linkage. J Neurol Psychiatry 1943;6:154-157.

65. Mazzocco MMM. Advances in research on the fragile X syndrome. Ment Retard Dev Disabil Res Rev 2000;6:96-106.

66. Bailey DB, Hatton DD, Skinner M. Early developmental trajectories of males with fragile X syndrome. Am J Ment Retard 1998;1:29-39.

67. Hagerman RJ. Physical and behavioral phenotype. In: Hagerman RJ, Cronister A, Fragile X syndrome: diagnosis, treatment, and research. Baltimore: Johns Hopkins University Press, 1996:3-88.

68. Bailey DB, Mesibov GB, Hatton DD, Clark RD, Roberts JE, Mayhew L. Autistic behavior in young boys with fragile X syndrome. J Autism Dev Dis 1998;28:499508.

69. Wolff PH, Gardner J, Lappen J, Paccia J, Meryash D. Variable expression of the fragile X syndrome in heterozygous females of normal intelligence. Am J Med Genet 1988;30:213-225.

70. Rousseau F, Heitz D, Tarleton J, Macpherson J, Malmgren H, Dahl N, Barnicoat A. A multicenter study on genotype-phenotype correlations in fragile X syndrome, using direct diagnosis with probe StB128: the first 2,253 cases. Am J Hum Genet 1994;55:225-237.

71. de Vries BBA, Wiegers AM, Smits APT, Mohkamsing S, Duivenvoorden HJ, Fryns J-P, Curfs LMG, Halley DJJ, Oostra BA, van den Ouweland AMW, Niermeijer MF. Mental status of females with an FMR1 gene full mutation. Am J Hum Genet 1996;58:1025-1032.

72. Reiss AL, Freund L, Abrams MT, Boehm C, Kazazian H. Neurobehavioral effects of the fragile X premutation in adult women: a controlled study. Am J Hum Genet $1993 \cdot 52 \cdot 884-894$

73. Hull C, Hagerman RJ. A study of the physical, behavioral, and medical phenotype, including anthropometric measures, of females with the fragile $\mathrm{X}$ syndrome. Am J Dis Child 1993;147:1236-1241.

74. Mazzocco MMM, Pennington BF, Hagerman RJ. The neurocognitive phenotype of female carriers of fragile X: additional evidence for specificity. J Dev Behav Pediatr 1993;14:328-335.

75. Loesch DZ, Hay DA, Mulley J. Transmitting males and carrier females in fragile X-revisited. Am J Med Genet 1994;51:392-399.

76. Allingham-Hawkins DJ, Brown CA, Babul R, Chitayat D, Krekewich K, Humphries T, Ray PN, Teshima IE. Tissue-specific methylation differences and cognitive function in fragile X premutation females. Am J Med Genet 1996;64:329333.

77. Franke P, Maier W, Hautzinger M, Weiffenbach O, Gansicke M, Iwers B, Poustka F, Schwab SG, Froster U. Fragile-X carrier females: evidence for a distinct psychopathological phenotype? Am J Med Genet 1996;64:334-339.

78. Riddle JE, Cheema A, Sobesky WE, Gardner SC, Taylor AK, Pennington BF, Hagerman RJ. Phenotypic involvement in females with the FMR1 gene mutation. Am J Ment Retard 1998;102:590-601.

79. Franke P, Leboyer M, Gansicke M, Weiffenbach O, Biancalana V, CornilletLefebre P, Delobel B, Froster U, Schwab SG, Poustka F, Hautzinger M, Maier W. Genotype-phenotype relationship in female carriers of the premutation and full mutation of FMR-1. Psychiatr Res 1998;80:113-127.

80. Tassone F, Hagerman R, Taylor AK, Gane LW, Hagerman PJ. Elevated levels of FMR1 mRNA in carrier males: a new mechanism of involvement in the fragile $\mathrm{X}$ syndrome. Am J Hum Genet 2000;66:6-15.

81. Kenneson A, Zhang F, Hagedorn CH, Warren ST. Reduced FMRP and increased FMR1 transcription is proportionally associated with CGG repeat number in intermediate-length and premutation carriers. Hum Mol Genet 2001;10:1449-1454. 
82. Tassone F, Hagerman RJ, Chamberlain WD, Hagerman PJ. Transcription of the FMR1 gene in individuals with fragile X syndrome. Am J Med Genet 2000;97:195203.

83. Sherman SL. Premature ovarian failure in the fragile X syndrome. Am J Med Genet 2000;97:189-194.

84. Helderman-van den Enden AT, Maaswinkel-Mooij PD, Hoogendoorn E, Willemsen R, Maat-Kievit JA, Losekoot M, Oostra BA. Monozygotic twin brothers with the fragile X syndrome: different CGG repeat and different mental capacities. J Med Genet 1999;36:253-257.

85. Willemsen R, Olmer R, De Diego Otero Y, Oostra BA. Twin sisters, monozygotic with the fragile X mutations, but with a different phenotype. J Med Genet 2000;37: 603-604.

86. Sheldon L, Turk J. Monozygotic boys with fragile X syndrome. Dev Med Child Neurol 2000;42:768-774.

87. Tassone F, Hagerman RJ, Ikle DN, Dyer PN, Lampe M, Willemsen R, Oostra BA, Taylor AK. FMRP expression as a potential prognostic indicator in fragile X syndrome. Am J Med Genet 1999;84:250-261.

88. Backes M, Genc B, Schreck J, Doerfler W, Lehmkuhl G, von Gontard A. Cognitive and behavioral profile of fragile X boys: correlations to molecular data. Am J Med Genet 2000;95:150-156.

89. Bailey DB, Hatton DD, Skinner M, Mesibov G. Autistic behavior, FMR1 protein, and developmental trajectories in young males with fragile X syndrome. J Autism Dev Dis 2001;31:165-174.

90. Burman RW, Anoe KS, Popovich BW. Fragile X full mutations are more similar in siblings than in unrelated patients: further evidence for a familial factor in CGG repeat dynamics. Genet Med 2000;2:242-248.

91. Nolin SL, Houck GE, Gargano AD, Blumstein H, Dobkin CS, Brown WT. FMR1 CGG-repeat instability in single sperm and lymphocytes of fragile-X premutation males. Am J Hum Genet 1999;65:680-688.

92. Crawford DC, Wilson B, Sherman SL. Factors involved in the initial mutation of the fragile X CGG repeat as determined by sperm small pool PCR. Hum Mol Genet 2000;9:2909-2918.

93. Murray J, Cuckle H, Taylor G, Hewison J. Screening for fragile X syndrome: information needs for health planners. J Med Screen 1997;4:60-94.

94. Gronskov K, Hallberg A, Brondum-Nielsen K. Mutational analysis of the FMR1 gene in 118 mentally retarded males suspected of fragile $\mathrm{X}$ syndrome: absence of prevalent mutations. Hum Genet 1998;102:440-445.

95. Willemsen R, Mohkamsing S, de Vries BA, Devys D, van den Ouweland A, Mandel J-L, Galjaard H, Oostra BA. Rapid antibody test for fragile X syndrome. Lancet 1995;345:1147-1148.

96. Willemsen R, Smits A, Mohkamsing S, van Beerendonk H, de Haan A, de Vries B, an den Ouweland A, Sistermans E, Galjaard H, Oostra BA. Rapid antibody test for diagnosing fragile X syndrome: a validation of the technique. Hum Genet 1997;99: $308-311$.

97. de Vries BBA, Mohkamsing S, van den Ouweland AMW, Halley DJJ, Niermeijer MF, Oostra BA, Willemsen R. Screening with the FMR1 protein test among mentally retarded males. Hum Genet 1998;103:520-522.

98. Willemsen R, Anar B, De Diego Otero Y, de Vries BBA, Hilhorst-Hofstee Y, Smits A, van Looveren E, Willems PJ, Galjaard H, Oostra BA. Noninvasive test for fragile X syndrome, using hair root analysis. Am J Hum Genet 1999;65:98-103.

99. Tuncbilek E, Alikasifoglu M, Aktas D, Duman F, Yanik H, Anar B, Oostra BA, Willemsen R. Screening for the fragile $\mathrm{X}$ syndrome among mentally retarded males by hair root analysis. Am J Med Genet 2000;95:105-107.

100. Jenkins EC, Wen GY, Kim KS, Zhong N, Sapienza VJ, Hong H, Chen J, Li S-Y, Houck GE, Ding X, Nolin SL, Dobkin CS, Brown WT. Prenatal fragile X detection using cytoplasmic and nuclear-specific monoclonal antibodies. Am J Med Genet 1999;83:342-346.

101. Lambiris N, Peters H, Bollmann R, Leschik G, Leisti J, Salonen R, Cobet G, Oostra BA, Willemsen R. Rapid FMR1-protein analysis of fetal blood: an enhancement of prenatal diagnostics. Hum Genet 1999;105:258-260.

102. American College of Medical Genetics. Fragile X syndrome: diagnostic and carrier testing. Am J Med Genet 1994;53:380-381.

103. Curry CJ, Stevenson RE, Aughton D, Byrne J, Carey JC, Cassidy S, Cunniff C, Grahman JM, Jones MC, Kaback MM, Moeschler J, Schaefer GB, Schwartz S, Tarleton J, Opitz J. Evaluation of mental retardation: recommendations of a consensus conference. Am J Med Genet 1997;72:468-477.

104. White BJ, Ayad M, Fraser A, Entwistle T, Winkler S, Sbeiti A, Fenwick R. A 6-year experience demonstrates the utility of screening for both cytogenetic and FMR-1 abnormalities in patients with mental retardation. Genet Testing 1999;3:291-296.

105. Hunter AGW. Outcome of the routine assessment of patients with mental retardation in a genetics clinic. Am J Med Genet 2000;90:60-68.

106. Stoll C. Problems in the diagnosis of fragile X syndrome in young children are still present. Am J Med Genet 2001;100:110-115.
107. Lachiewicz AM, Dawson DV, Spiridigliozzi GA. Physical characteristics of young boys with fragile $\mathrm{X}$ syndrome: reasons for difficulties in making a diagnosis in young males. Am J Med Genet 2000;92:229-236.

108. Schwartz CE, Phelan MC, Pulliam LH, Wilkes G, Vanner LV, Albiez KL, Potts WA, Rogers RC, Schroer RJ, Saul RA, Prouty LA, Dean JH, Taylor HA, Stevenson RE. Fragile X. syndrome: incidence, clinical and cytogenetic findings in the black and white populations of South Carolina. Am J Med Genet 1988;30:641-654.

109. Epps S, Kroeker R. Effects of child age and level of developmental delay on family practice physicians' diagnostic impressions. Ment Retard 1995;33:35-41.

110. Bailey DB, Skinner D, Hatton D, Roberts J. Family experiences and factors associated with the diagnosis of fragile X syndrome. J Dev Behav Pediatr 2000;21:315321.

111. Brown WT, Nolin SL, Houck GE, Ding X, Glicksman AE, Li S-Y, Stark-Houck S, Brophy P, Duncan C, Dobkin C, Jenkins EC. Prenatal diagnosis and carrier screening for fragile X by PCR. Am J Med Genet 1996;64:191-195.

112. Howard-Peebles PN, Maddalena A, Black SH, Levison G, Bick DD, Schulman JD. Fragile X screening in pediatric and obstetrical patients. Dev Brain Dysfunct 1995; 8:408-410.

113. Wenstrom KD, Descartes M, Franklin J, Cliver SP. A five-year experience with fragile X screening of high-risk gravid women. Am J Obstet Gynecol 1999;181:789792.

114. Kallinen J, Heinonen S, Mannermaa A, Ryynanen M. Prenatal diagnosis of fragile X syndrome and the risk of expansion of a premutation. Clin Genet 2000;58:111115.

115. Robinson H, Wake S, Wright F, Laing S, Turner G. Informed choice in fragile X syndrome and its effects on prevalence. Am J Med Genet 1996;64:198-202.

116. Newborn Screening Task Force. Serving the family from birth to the medical home. A report from the newborn screening task force convened in Washington DC, May 10-11, 1999. Pediatrics 2000;106:379-427.

117. van der Riet AA, van Hout BA, Rutten FFH. Cost effectiveness of DNA diagnosis for four monogenic diseases. J Med Genet 1997;34:741-745.

118. Wildhagen MF, van Os TAM, Polder JJ, ten Kate LP, Habbema JDF. Explorative study of costs, effects and savings of screening for female fragile X premutation and full mutation carriers in the general population. Community Genet 1998;1:36-47.

119. Bailey DB, Roberts JE, Mirrett P, Hatton DD. Identifying infants and toddlers with fragile X syndrome: issues and recommendations. Inf Young Children 2001;14(1): $24-33$.

120. Wildhagen MF, van Os TAM, Polder JJ, ten Kate LP, Habbema JDF. Efficacy of cascade testing for fragile X syndrome. J Med Screen 1999;6:70-76.

121. Murray A, Youings SA, Dennis N, Latsky L, Linehan P, McKechnie N, Macpherson J, Pound M, Jacobs P. Population screening at the FRAXA and FRAXE loci: molecular analyses of boys with learning difficulties and their mothers. Hum Mol Genet 1996;5:727-735.

122. Crawford DC, Meadows KL, Newman JL, Taft LF, Pettay DL, Gold LB, Hersey SJ, Hinkle EF, Stanfield ML, Holmgreen P, Yeargin-Allsopp M, Boyle C, Sherman SL. Prevalence and phenotype consequence of FRAXA and FRAXE alleles in a large, ethnically diverse, special education-needs population. Am J Hum Genet 1999;64: 495-507.

123. Gerard B, Le Heuzey MF, Brunie G, Lewine P, Saiag MC, Cacheux V, Da Silva F, Dugas M, Mouren-Simeoni MC, Elion J, Grandchamp B. Systematic screening for fragile X syndrome in a cohort of 574 mentally retarded children. Ann Genet 1997; 40:139-144.

124. Zhong N, Ju W, Xu W, Ye L, Shen Y, Wu G, Chen S-H, Jin R, Hu X-F, Yang A, Liu X, Poon P, Pang C, Zheng Y, Song L, Zhao P, Fu B, Gu H, Brown WT. Frequency of the fragile $\mathrm{X}$ syndrome in Chinese mentally retarded populations is similar to that in Caucasians. Am J Med Genet 1999;84:191-194.

125. Jain U, Verma IC, Kapoor AK. Prevalence of fragile X(A) syndrome in mentally retarded children at a genetics referral centre in Delhi, India. Indian J Med Res 1998;108:12-16.

126. Arvio M, Peippo M, Simola KOJ. Applicability of a checklist for clinical screening of the fragile X syndrome. Clin Genet 1997;52:211-215.

127. Hagerman RJ, Wilson P, Staley LW, Lang KA, Fan T, Uhlhorn C, Jewell-Smart S, Hull C, Drisko J, Flom K, Taylor AK. Evaluation of school children at high risk for fragile X syndrome utilizing buccal cell FMR-1 testing. Am J Med Genet 1994;51: $474-481$.

128. Hofstee Y, Arinami T, Hamaguchi H. Comparison between the cytogenetic test for fragile $\mathrm{X}$ and the molecular analysis of the FMR-1 gene in Japanese mentally retarded individuals. Am J Med Genet 1994;51:466-470.

129. Faradaz SMH, Buckley M, Tang L-P, Leigh D, Holden JJA. Molecular screening for fragile $\mathrm{X}$ syndrome among Indonesian children with developmental disability. Am J Med Genet 1999;83:350-351.

130. Syrrou M, Georgiou I, Grigoriadou M, Petersen MB, Kitsiou S, Pagoulatos G, Patsalis PC. FRAXA and FRAXE prevalence in patients with nonspecific mental retardation in the Hellenic population. Genet Epidemiol 1998;15:103-109. 
131. Haddad LA, Aguiar MJB, Costa SS, Mingroni-Netto RC, Vianna-Morgante AM, Pena SDJ. Fully mutated and gray-zone FRAXA alleles in Brazilian mentally retarded boys. Am J Med Genet 1999;84:198-201.

132. Nanba E, Kohno Y, Matsuda A, Yano M, Sato C, Hashimoto K, Koeda T, Yoshino K, Kimura M, Maeoka Y, Yamamoto T, Maegaki Y, Eda I, Takeshita K. Nonradioactive DNA. diagnosis for the fragile $\mathrm{X}$ syndrome in mentally retarded Japanese males. Brain Dev 1995;17:317-321.

133. Tan BS, Law HT, Zhao Y, Yoon CS, Ng ISL. DNA testing for fragile X syndrome in 255 males from special schools in Singapore. Ann Acad Med Singapore 2000;29:207-212.

134. Pang CP, Poon PMK, Chen QL, Lai KYC, Yin CH, Zhao Z, Zhong N, Lau CH, Lam STS, Wong CK, Brown WT. Trinucleotide CGG repeat in the FMR1 gene in Chinese mentally retarded patients. Am J Med Genet 1999;84:179-183.

135. Morton JE, Bundey S, Webb TP, MacDonald F, Rindl PM, Bullock S. Fragile X syndrome is less common than previously estimated. J Med Genet 1997;34:1-5.

136. Aspillaga HM, Jara SL, Avendano BI, Lopez SM. Fragile X syndrome. Clinical analysis of 200 Chilean patients with unspecific mental retardation. Rev Med Chile 1998;126:1447-1454.

137. Tzeng CC, Tzeng P-Y, Sun HS, Chen RM, Lin S-J. Implication of screening for FMR1 and FMR2 gene mutation in individuals with nonspecific mental retardation in Taiwan. Diagn Mol Pathol 2000;9:75-80.

138. van den Ouweland AMW, de Vries BBA, Bakker PLG, Deelen WH, de Graaff E, van Hemel JO, Oostra BA, Niermeijer MF, Halley DJJ. DNA diagnosis of the fragile X syndrome in a series of 236 mentally retarded subjects and evidence for a reversal of mutation in the FMR-1 gene. Am J Med Genet 1994;51:482-485.

139. Kaplan G, Kung M, McClure M, Cronister A. Direct mutation analysis of 495 patients for fragile X carrier status/proband diagnosis. Am J Med Genet 1994;51:501-502.

140. Mila M, Sanchez A, Badenas C, Brun C, Jimenez D, Villa MP, Castellvi-Bel S, Estivill X. Screening for FMR1 and FMR2 mutations in 222 individuals from Spanish special schools: identification of a case of FRAXE-associated mental retardation. Hum Genet 1997;100:503-507.

141. Tuncbilek E, Alikasifoglu M, Boduroglu K, Aktas D, Anar B. Frequency of fragile X syndrome among Turkish patients with mental retardation of unknown etiology. Am J Med Genet 1999;84:202-203.

142. Goldman A, Krause A, Jenkins T. Fragile X syndrome occurs in the South African black population. SAMJ 1997;87:418-420

143. Goldman A, Jenkins T, Krause A. Molecular evidence that fragile X syndrome occurs in the South African black population. J Med Genet 1998;35:878
144. O'Dwyer J, Holmes J, Mueller R, Taylor G. The prevalence of fragile X syndrome in an institution for people with learning disability. Psychiatr Genet 1997;7:115-119.

145. Ruangdaraganon N, Limprasert P, Sura T, Sombuntham T, Sriwongpanich N, Kotchabhakdi N. Prevalence and clinical characteristics of fragile X syndrome at child development clinic, Ramathibodi hospital. J Med Assoc Thai 2000;83:69-76.

146. Sharma D, Gupta M, Thelma BK. Expansion mutation frequency and CGG/GCC repeat polymorphism in FMR1 and FMR2 genes in an Indian population. Genet Epidemiol 2001;20:129-144.

147. Hagerman R, Amiri K, Cronister A. Fragile X checklist. Am J Hum Genet 1991;38: 283-287.

148. Mulatinho MV, Llerena JC, Pimentel MMG. FRAXA screening in Brazilian institutionalized individuals with nonspecific severe mental retardation. Genet Testing 2000;4:283-287.

149. Hecimovic S, Barisic I, Pavelic K. DNA analysis of the fragile X syndrome in an at risk pediatric population in Croatia: simple clinical preselection criteria can considerably improve the cost-effectiveness of fragile X screening studies. Hum Hered 1998;48:256-265.

150. Gonzalez-del Angel A, Vidal S, Saldana Y, del Castillo V, Alcantara MA, Macias M, Luna JP, Orozco L. Molecular diagnosis of the fragile X and FRAXE syndromes in patients with mental retardation of unknown cause in Mexico. Ann Genet 2000;43: $29-34$.

151. Holden JJA, Chalifoux M, Wing M, Julien-Inalsingh C, Lawson JS, Higgins JV, Sherman S, White BN. Distribution and frequency of FMR1 CGG repeat numbers in the general population. Dev Brain Dysfunct 1995;8:405-407.

152. Dawson AJ, Chodirker BN, Chudley AE. Frequency of FMR1 premutations in a consecutive newborn population by PCR screening of Guthrie blood spots. Biochem Mol Med 1995;56:63-69.

153. Reiss AL, Kazazian HH, Krebs CM, McAughan A, Boehm CD, Abrams MT, Nelson DL. Frequency and stability of the fragile X premutation. Hum Mol Genet 1994;3:393398.

154. Mazzocco MMM, Sonna NL, Teisl JT, Pinit A, Shapiro BK, Shah N, Reiss AL. The FMR1 and FMR2 mutations are not common etiologies of academic difficulty among school-age children. J Dev Behav Pediatr 1997;18:392-398.

155. Snow K, Doud LK, Hagerman R, Pergolizzi RG, Erster SH, Thibodeau SN. Analysis of a CGG sequence at the FMR-1 locus in fragile $\mathrm{X}$ families and in the general population. Am J Hum Genet 1993;53:1217-1228.

\section{Appendix}

Online resources for the fragile X syndrome

Resource World Wide Web URL

Support Groups

The National Fragile X Foundation

FRAXA Research Foundation

Research

X-Linked Mental Retardation (XLMR)

Educational

Human Genome Epidemiology Network (HuGE Net) ${ }^{a}$

National Institute of Child Health and Human Development

Gene Clinics

Carolina Fragile X Project

The ARC of the United States

Genetic Databases

Online Mendelian Inheritance in Man (OMIM)

Human Gene Mutation Database

Policy

American Academy of Pediatrics

The American College of Medical Genetics http://nfxf.org

http://www.fraxa.org/

http://xlmr.interfree.it/home.htm

http://www.cdc.gov/genetics/hugenet/default.htm

http://www.nichd.nih.gov

http://www.geneclinics.com/profiles/fragilex/details.html

http://www.fpg.unc.edu/ fx/index.htm

http://www.thearc.org

http://www.ncbi.nlm.nih.gov/htbin-post/Omim/dispmim?309550

http://archive.uwcm.ac.uk/uwcm/mg/search/129038.html

http://www.aap.org/

http://www.faseb.org/genetics/acmg/pol-16.htm

http://www.faseb.org/genetics/acmg/index.html

${ }^{a}$ This review will be published on the HuGE Net Web site with modifications. 